\title{
Profitability and Sustainable Use of Traps for Amazon \\ Shrimp (Macrobrachium amazonicum) From the
}

\section{Amazon River}

Odair de Almeida Melo

Masters of Science, Tropical Aquaculture and Aquatic Resources Program PPGAQRAT - Universidade Federal Rural da Amazônia - UFRA - Avenida Presidente

Tancredo Neves, № 2501, Terra Firme, 66077-830, Belém, PA, Brazil.

E-mail: odair.dealmeidamelo@gmail.com

\section{Luís Mauricio Abdon da Silva}

Scientific and Technological Research Institute of the State of Amapá - Núcleo de Pesquisas Aquáticas - IEPA/NUPAq, Campus da Fazendinha. Rodovia Juscelino Kubitschek, km 10, Fazendinha, 68903-419 Macapá, AP, Brazil. E-mail:luis.abdon13@gmail.com

Pedro Henrique Campos Sousa (Corresponding author)

Masters of Science, Tropical Aquaculture and Aquatic Resources Program PPGAQRAT - Universidade Federal Rural da Amazônia - UFRA - Avenida Presidente

Tancredo Neves, № 2501 Bairro: Terra Firme, 66.077-830, Belém, PA, Brazil.

E-mail:pedropesca13@gmail.com

\section{Sirley Luzia Figueiredo Silva}

Scientific and Technological Research Institute of the State of Amapá - Núcleo de Pesquisas Aquáticas - IEPA/NUPAq, Campus da Fazendinha. Rodovia Juscelino Kubitschek, km 10, Fazendinha, CEP: 68903-419 Macapá, Amapá, Brazil. E-mail:sirleyfig@ gmail.com

Jô de Farias Lima

Brazilian Agricultural Research Corporation - Embrapa Amapá. Rodovia Juscelino Kubitschek, km 5, n²600, 68906-970, Caixa Postal 10, Macapá, AP, Brazil.

Luiz Claudio Feitoza dos Santos Júnior 


\title{
Ml Macrothink
}

State University of Amapá, Curso de Engenharia de Pesca. Av. Presidente Vargas, $\mathrm{n}^{\circ}$ 650, 68900-000. Macapá, Amapá, Brazil. E-mail: luizjunioramapa@gmail.com

\section{Libna Gomes Fernandes}

State University of Amapá, Curso de Engenharia Ambiental. Av. Presidente Vargas, $\mathrm{n}^{\circ}$ 650, 68900-000. Macapá, Amapá, Brazil. E-mail:bidafernandes06@gmail.com

\section{Kátia Cristina de Araújo Silva}

Socioambiental and Hydrological Resources Institute - ISARH, Laboratório de Crustáceos - LABCRUS, Universidade Federal Rural da Amazônia - UFRA - Avenida Presidente Tancredo Neves, Nº 2501 Bairro: Terra Firme, 66.077-830, Belém, PA, Brasil. E-mail: katia.silva@ufra.edu.br

\section{Israel Hidenburgo Aniceto Cintra}

Socioambiental and Hydrological Resources Institute - ISARH, Laboratório de Crustáceos - LABCRUS, Universidade Federal Rural da Amazônia - UFRA - Avenida Presidente Tancredo Neves, No 2501 Bairro: Terra Firme,66.077-830, Belém, PA, Brazil. E-mail: israel.cintra@ufra.edu.br

Received: Mar. 29, 2020

doi:10.5296/jas.v8i3.16755
Accepted: Apr. 21, $2020 \quad$ Published: May 6, 2020

URL: https://doi.org/10.5296/jas.v8i3.16755

\begin{abstract}
The objective of this study was to evaluate the profitability, productivity and selectivity of traps used for the capture of freshwater prawn using different spacings between the laths. This study was developed in the estuary of the Amazon River near Santana island, Amapá, Brazil. Collections were conducted using traps called "matapi", which are cylindrical shrimp traps made with wooden slats or laths, with funnel-shaped entrances at both sides, and the spacings between the laths ranged between 1 to $10 \mathrm{~mm}$ in $1 \mathrm{~mm}$ increments. Each trap was covered with a net called a "sobrematapi", or trap cover. The length of carapace in centimeters and the weight in grams were measured for all specimens. The shrimp were categorized into small, medium, and large size classes. Selectivity curves were used to determine selectivity for the different lath spacings. Traps with lath spacing below $7 \mathrm{~mm}$ should be considered as being predatory because they allow for the capture of small individuals, with more than $50 \%$ of these being captured using spacings from 1 to $5 \mathrm{~mm}$. Despite the fact that spacings between 8 and $10 \mathrm{~mm}$ captured lower quantities of shrimp, this
\end{abstract}


enabled the capture of larger specimens with a similar total biomass yield, and this spacing is considered to be the most ecologically and economically viable. In order to minimize the capture of young shrimp without drastically affecting economic yield, it is suggested that shrimp trap lath spacings be above $6 \mathrm{~mm}$.

Keywords: regional shrimp, harvesting, traps, small-scale fishery

\section{Introduction}

For many years Amazonian rivers have been one of the principal sources of food for human populations. Currently, the demand for food sources is rapidly increasing, and animal production is not able to satisfy the demand for protein by the growing human population (Sainsbury, 1986; Delgado et al., 2003), and the high yields of fisheries, especially those from developing countries, has contributed to the increase in production of global fisheries (Swartz et al., 2010). According to the United Nations Food and Agriculture Organization (FAO), about 19\% of world fishery stocks were overexploited in 2007 (FAO, 2012). Biello (2006) predicted that in 2048 all fish and shellfish stocks in the world would be practically exhausted, with no possibility of recuperation.

Fishery resources that are not overexploited are those that have some type of regulation and have strong governance and control over the territory in which they are located, including quota systems and management and protection areas (Worm et al., 2009). Although Macrobrachium amazonicum (Heller, 1862) is an economically important fishing resource that is the most exploited and consumed by populations in the Amazon and semiarid areas in the Northeast region of the country (Moraes-Valenti and Valenti, 2010; Aya-Baquero and Velasco-Santamaría, 2013), there is no regulation of the fishery resource.

A large part of the riverine communities in the region capture this shrimp using artisanal fishing methods using equipment such as the matapí (which are cylindrical traps made with wooden slats or laths, with funnel-shaped entrances at both sides, with laths made of material from the juruti or buriti palms), or a shrimp net made of nylon that is thrown out over the water. In the estuary of the Amazon capture of the Amazonian shrimp has intensified during the last few years, causing a reduction in natural stocks. The process of capture of this shrimp frequently involves the use of traps that are locally known as matapis. Compared to drag nets and puçás (dip nets), the matapi has demonstrated better economic and environmental results, because besides considerably minimizing capture of other species of fauna together with the shrimp they require a lower expenditure of time and energy for the capture of fauna (Vieira and Araújo-Neto, 2006). Through informal conversations with residents that fish for shrimp as a complement to their income, or that make a living exclusively as a fisherman, there is evidence that the high intensity of fishing in the region could have contributed to a decrease in the population of this Amazonian shrimp (Personal Communication).

In general, fishing equipment, when used by fishermen or researchers, is selective, meaning that they capture only species that are within a certain size of length. For this reason, if someone has an interest in describing the size distribution of a population it is necessary to explain the effect of selectivity and there are few studies on selectivity for Macrobrachium 
amazonicum (Costa et al., 2016; Lima et al., 2016; Bentes et al., 2014; Lima and Montagner, 2014). The objective of this work was to evaluate the profitability, productivity and selectivity of traps used for the capture of these shrimp using different spacings between the laths.

\section{Materials and Methods}

This study was conducted in the estuary of the Amazon River near Santana island, city of Santana, in the state of Amapá, Brazil (Figure 1). The island is located at the coordinates $51^{\circ}$ $08^{\prime} 00^{\prime}$ " and $51^{\circ} 12^{\prime} 10^{\prime \prime}$ longitude (West) and $00^{\circ} 03^{\prime} 35^{\prime \prime}$ and $00^{\circ} 06^{\prime} 00^{\prime}$ ' latitude (South) (Silva et al., 2007).
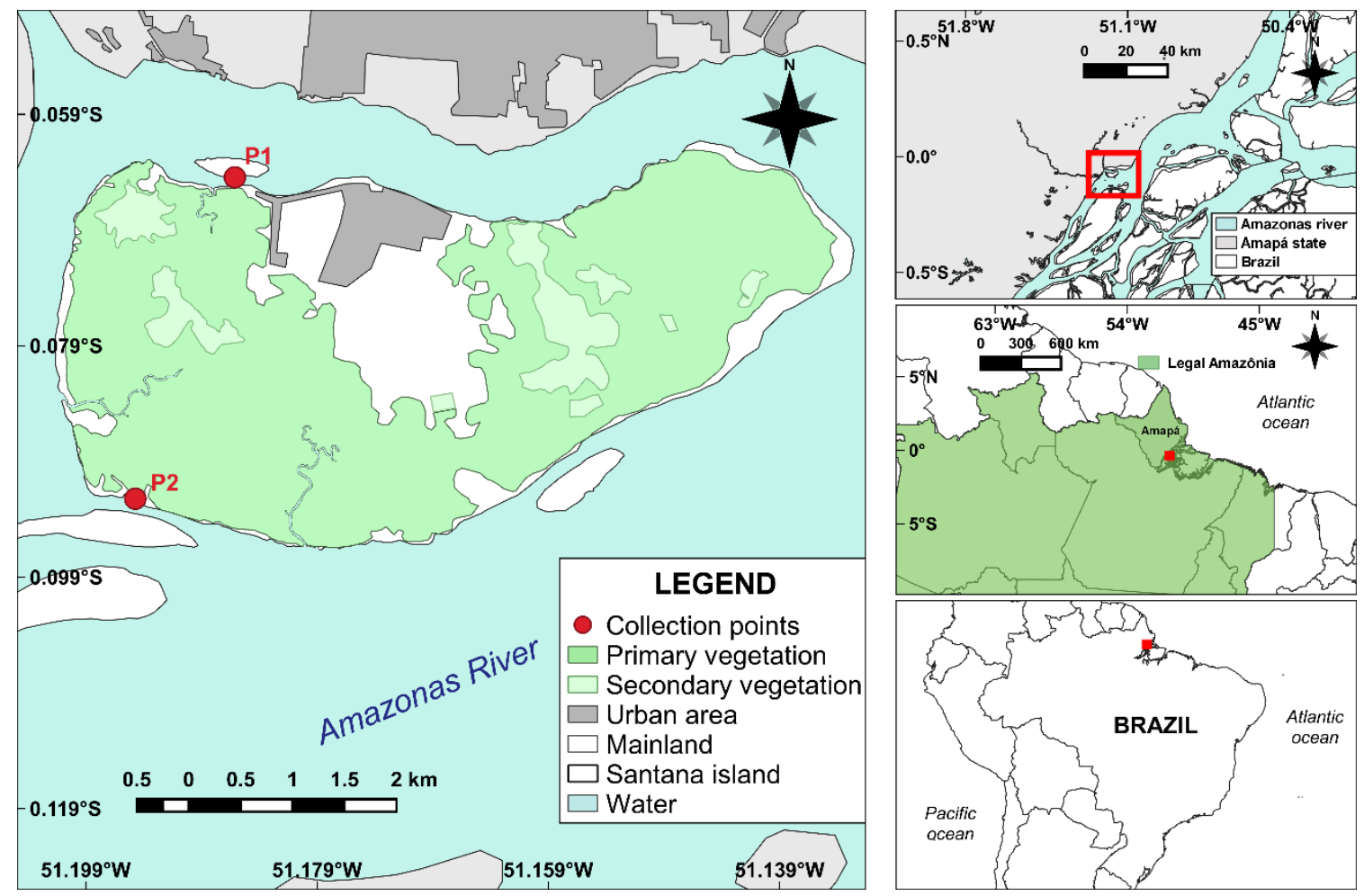

Figure 1. Location of Santana island

In order to incorporate seasonal climate variation in sample collection, a total of twelve monthly collections (May 2018 to April 2019) were conducted at two points on Santana island. According to the fishermen, placing traps always in the same place causes the shrimp to move to another environment, therefore two alternate collection points were chosen each month.

Collections were done using a trap referred to as a "matapi" (Figure 2) in the northern coastal region of Brazil. At each of the two collection points three "matapis" with different sizes of the spaces between the laths $(1,2,3,4,5,6,7,8,9$, and $10 \mathrm{~mm})$ were distributed, totaling 30 matapis. Each matapi was covered with a type of mosquito net, denominated a matapi cover, with the function of retaining shrimp that had escaped from the matapi (Costa et al., 2016). 


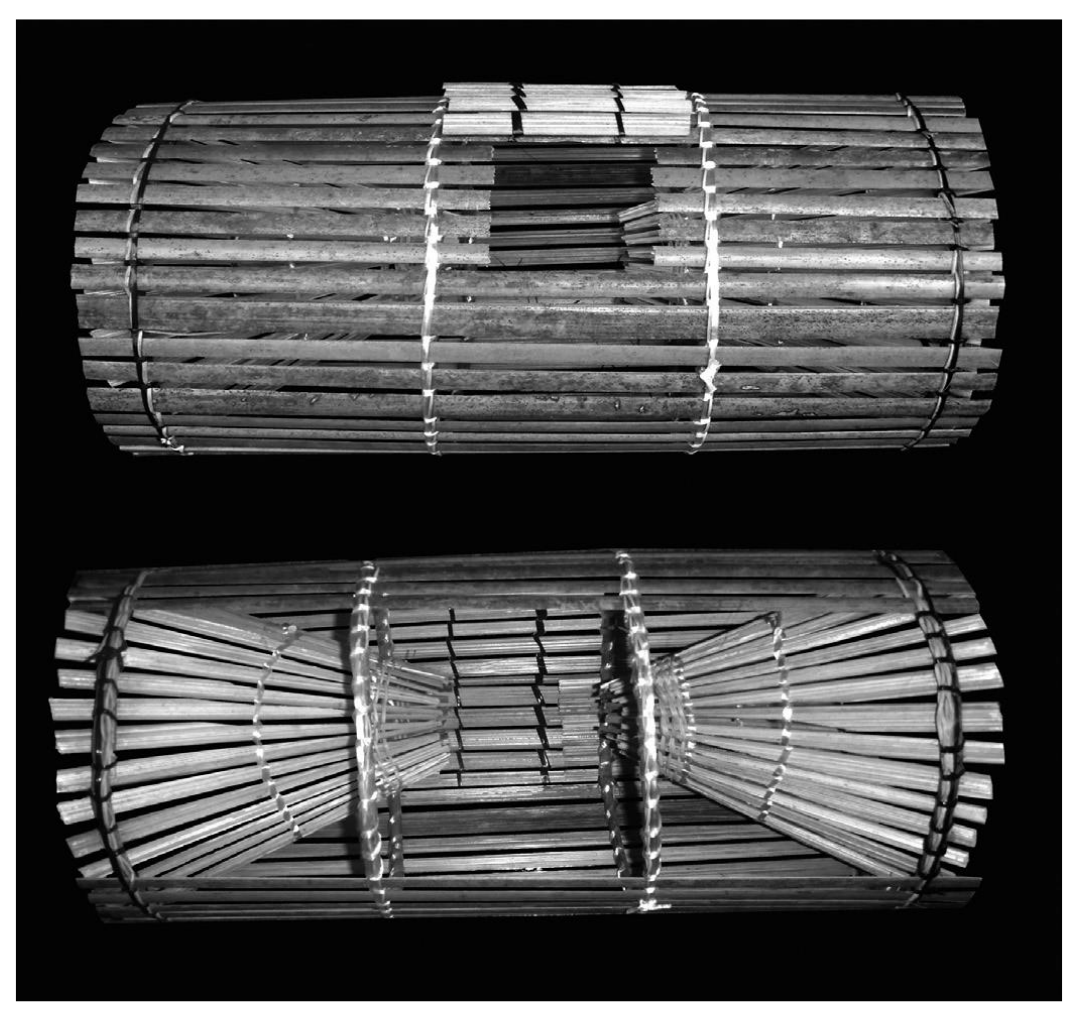

Figure 2. Traditional trap used in shrimp fishing. Photo: Jô de Farias Lima

The matapis were randomly distributed in the water at 18:00 and removed at 6:00 on the next day for a total of 12 hours of sampling. The captured shrimp, alive or dead, were placed in 1 $\mathrm{kg}$ plastic bags that were labeled with information about how they were captured (matapi or matapi cover), date, and lath spacing. For the shrimp collection, all captured specimens were separated by species, counted, weighed and preserved in $70 \%$ alcohol and deposited in the Laboratory of Biology and Dynamics of Fishery Resources of IEPA - AP.

In the laboratory, shrimps have been identified down to the species level (Mello, 2003) and the length of carapace in centimeters and the weight in grams were measured for all specimens of $M$. amazonicum. After the biometry measurements the shrimp were classified into groups that comprised immature young, represented by individuals that had a length of carapace that was inferior to the length of carapace of the smallest egg-carrying female, and adults represented by individuals that had length of carapace equal or greater than that of the smallest egg-carrying female (Lima et al. 2014). The shrimp were classified into three size classes according to labeling practices used in the commercialization of this product: small: length of carapace LC $<1.00 \mathrm{~cm}$; medium: length of carapace $1.00 \leq \mathrm{LC} \leq 1.5 \mathrm{~cm}$; big: length of carapace LC > $1.5 \mathrm{~cm}$ (Lima, $2014 \mathrm{~b}$ ).

The data were analyzed using the Shapiro-Wilk normality test, and the Levene-Bartlett test was used to evaluate homogeneity and homoscedasticity (Zar, 1996).

Analysis of variance (one-way) was used to test shrimp length of carapace, biomass and quantity as a function of the spacing of the openings of the matapis. The analyses were run in PAST 3.17 (Hammer et al., 2001). The selectivity curves for the different spacings between 


\section{Macrothink

laths of the matapis were obtained using the method described by Pope et al., (1983); Jones (1976).

$$
S L=\frac{1}{1+E X P(S 1-S 2 * L)}
$$

Where $S L=$ number of shrimp with length $L$ in the matapi/ number of shrimp with length $L$ in the matapi plus those retained in the matapi cover; $L$, is the average of the interval of the carapace length, and S1 and S2 are constants. Rewriting the equation for the logistic curve yields:

$$
L N(1 / S L-1)=S 1-S 2 * L
$$

Which equals a straight line, where $S 1$ and $S 2$ represent, respectively, the parameters $a$ and $b$. The lengths, in which $25 \%, 50 \%$ and $75 \%$ of the shrimp are classified, were calculated using the equations:

$$
\begin{gathered}
L 25 \%=(S 1-L N 3) / S 2 \\
L 50 \%=S 1 / S 2 \\
L 75 \%=(S 1+L N 3) / S 2
\end{gathered}
$$

In order to determine the optimum spacing between the laths of the matapis, size at sexual maturation was taken to be $4.5 \mathrm{~cm}$ and 6.0 of total length (approximately $0.9 \mathrm{~cm}$ to $1.3 \mathrm{~cm}$ of length of carapace) (Bentes et al., 2016; Freire et al., 2012; Lima et al., 2014; Sampaio et al., 2007; Silva et al., 2005).

Productivity was determined by the number and biomass of captured shrimp in each trap type according to the size categories, and profitability was based on the prices of shrimp sold in markets. The shrimps caught by the fishermen are preserved on ice or marketed fresh (not live) to the brokers who separate the prawns by size (large, medium and small) to be sold to consumers, thus having more profitability.

\section{Results and Discussion}

A total of 19,967 were captured in all the traps employed in this study. The quantity of shrimp captured in the matapis was greater for those with closer spacing (1mm to $5 \mathrm{~mm}$ ) and represented $62 \%$ of all captured freshwater prawn (Figure 3). 


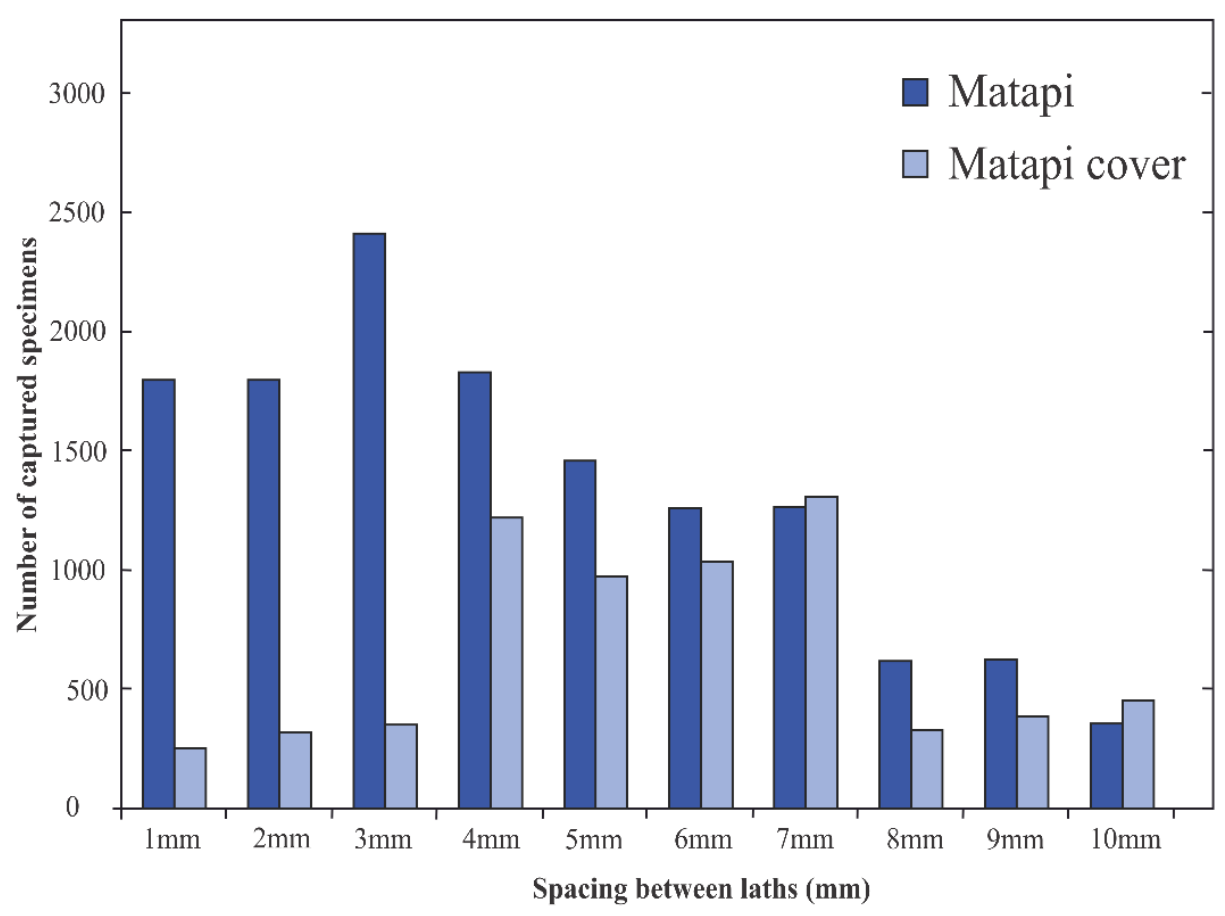

Figure 3. Quantity of freshwater prawn captured using different spacings between laths of the matapis. Data collected monthly between May 2018 and April 2019

In the lower Tocantins region, a maximum total length of $13.2 \mathrm{~cm}$ was reported, and samples from Tucuruí lake had a maximum total length of $8.0 \mathrm{~cm}$ (Odinetz-Collart, 1987). At Combú island, Silva (2006) registered a shrimp with a maximum total length of de $14.1 \mathrm{~cm}$, very similar to that from Vigia $(14.4 \mathrm{~cm})$ by Silva et al. (2002). Silva et al. (2005) found a maximum total length of $10.5 \mathrm{~cm}$ below the Tucuruí hydroelectric dam. Rocha et al. (2015), studying morphometric relationships in Amazonian shrimp in a reservoir in Bahia found shrimp with a maximum total length of $9.74 \mathrm{~cm}$. Freire et al. (2017) studied the morphometric characteristic of $M$. amazonicum in three localities in the Tocantins-Araguaia basin and at Cametá reported a maximum total length of $87.99 \mathrm{~mm}$, at Tucuruí $69.38 \mathrm{~mm}$ and at Soure $98.25 \mathrm{~mm}$, values that are well below those reported in the current study $(12.7 \mathrm{~cm})$. The maximum total length of adults tends to be greater in coastal environments than in interior waters (Silva et al., 2002; Flexa et al., 2005; Freire et al., 2012; Pantaleão et al., 2012).

A greater quantity of shrimp was captured using spacings between 3 and $4 \mathrm{~mm}$, while the lowest quantity captured was with a spacing $10 \mathrm{~mm}($ ANOVA F 9;110 $=3.688 ; \mathrm{p}=0.00045)$ (Figure 4). 


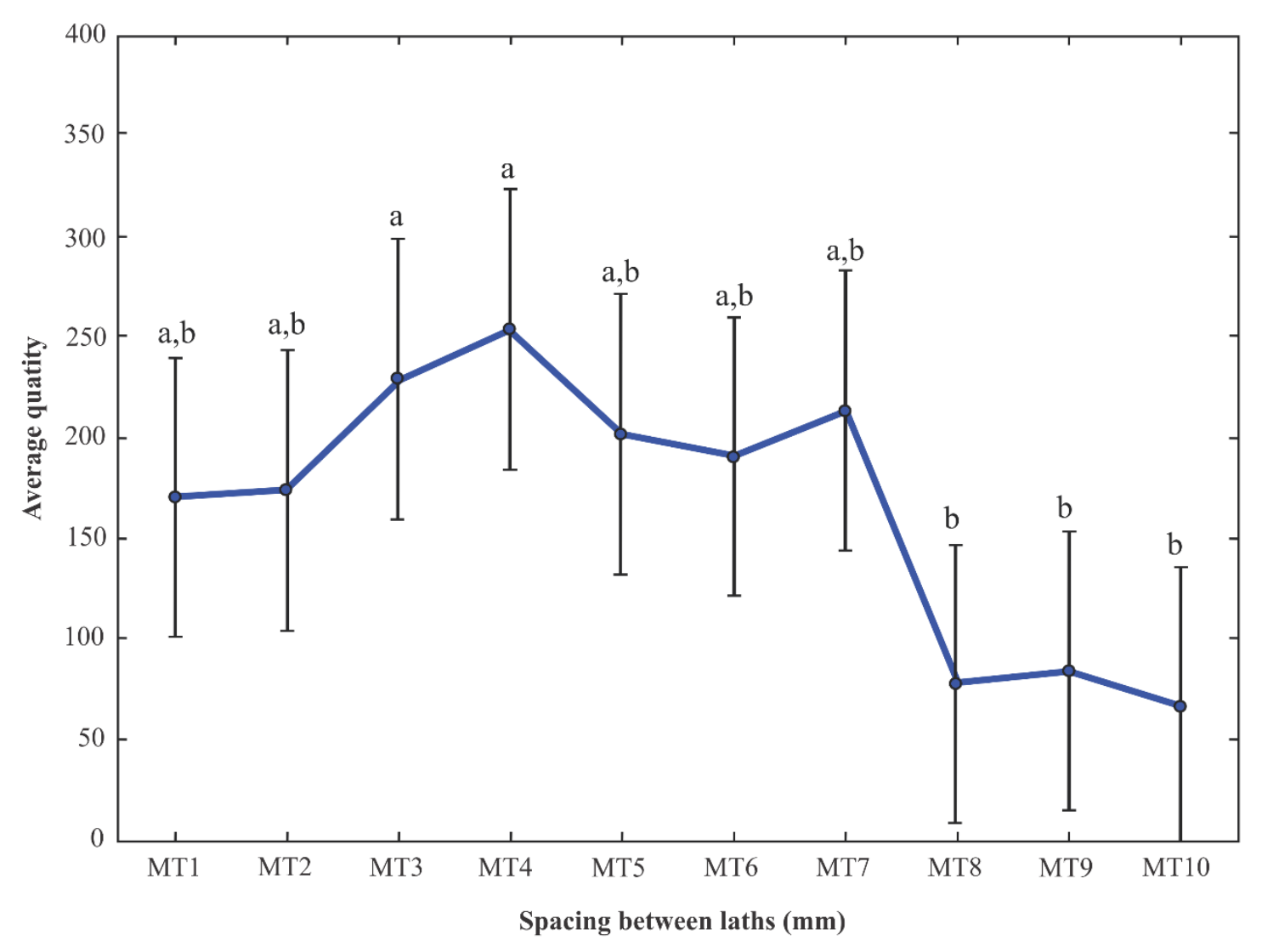

Figure 4. Average quantity of shrimp captured for each lath spacing. The bars indicate the confidence interval for the averages. Data collected monthly between May 2018 and April 2019. Values with the same lowercase letters are not significant

The number of small shrimps captured was 10,970 (54.94\%), for medium shrimp it was 5,227 (26.18\%), and for big the quantity was 3,770 (18.88\%). The percentages for small shrimp captured for all spacings was greater, except for spacings of 8 to $10 \mathrm{~mm}$ where big shrimp had greater percentages (Table 1).

With respect to economic yield, it was observed that big shrimp had greater yield for all lath spacings in spite of the lower number of shrimps captured for spacings between 1 and $7 \mathrm{~mm}$ (Table 1). The greater capture of big shrimp using spacings between 8 and $10 \mathrm{~mm}$ allowed for larger economic yield per capture (Table 1). 
Table 1. Abundance, biomass, percent of shrimp and profitability with respect to spacing between the laths of the matapi (matapi + matapi cover). Data collected monthly between May 2018 and April 2019. Size: B (Big), M (Medium), S (Small)

\begin{tabular}{|c|c|c|c|c|c|c|}
\hline & Size & Abundance & $\begin{array}{l}\text { Biomass } \\
(\mathrm{kg})\end{array}$ & $\begin{array}{l}\text { Percentage } \\
\text { (abundance) }\end{array}$ & Value of sale $(\mathrm{R} \$)$ & Total profit $(\mathrm{R} \$)$ \\
\hline \multirow{3}{*}{ MT1 } & B & 370 & 1.75 & 1.85 & 15 & 26.23 \\
\hline & M & 534 & 0.77 & 2.67 & 10 & 7.67 \\
\hline & S & 1144 & 0.58 & 5.73 & 6 & 3.49 \\
\hline \multirow{3}{*}{ MT2 } & B & 347 & 1.64 & 1.74 & 15 & 24.65 \\
\hline & M & 557 & 0.78 & 2.79 & 10 & 7.84 \\
\hline & S & 1187 & 0.64 & 5.94 & 6 & 3.83 \\
\hline \multirow{3}{*}{ MT3 } & B & 399 & 1.55 & 2.00 & 15 & 23.31 \\
\hline & M & 796 & 1.16 & 3.99 & 10 & 11.64 \\
\hline & S & 1558 & 0.82 & 7.80 & 6 & 4.89 \\
\hline \multirow{3}{*}{ MT4 } & B & 311 & 1.23 & 1.56 & 15 & 18.52 \\
\hline & M & 653 & 0.96 & 3.27 & 10 & 9.57 \\
\hline & S & 2087 & 0.95 & 10.45 & 6 & 5.70 \\
\hline \multirow{3}{*}{ MT5 } & B & 250 & 1.05 & 1.25 & 15 & 15.70 \\
\hline & M & 639 & 0.96 & 3.20 & 10 & 9.57 \\
\hline & S & 1534 & 0.78 & 7.68 & 6 & 4.68 \\
\hline \multirow{3}{*}{ MT6 } & B & 327 & 1.38 & 1.64 & 15 & 20.70 \\
\hline & M & 650 & 0.96 & 3.26 & 10 & 9.63 \\
\hline & S & 1315 & 0.78 & 6.59 & 6 & 4.70 \\
\hline \multirow{3}{*}{ MT7 } & B & 446 & 1.81 & 2.23 & 15 & 27.10 \\
\hline & $\mathrm{M}$ & 725 & 1.06 & 3.63 & 10 & 10.62 \\
\hline & $S$ & 1396 & 0.72 & 6.99 & 6 & 4.31 \\
\hline \multirow{3}{*}{ MT8 } & B & 419 & 2.00 & 2.10 & 15 & 30.01 \\
\hline & $\mathrm{M}$ & 161 & 0.26 & 0.81 & 10 & 2.60 \\
\hline & $S$ & 353 & 0.22 & 1.77 & 6 & 1.29 \\
\hline \multirow{3}{*}{ MT9 } & B & 486 & 2.13 & 2.43 & 15 & 32.02 \\
\hline & $\mathrm{M}$ & 232 & 0.43 & 1.16 & 10 & 4.32 \\
\hline & $S$ & 291 & 0.15 & 1.46 & 6 & 0.88 \\
\hline \multirow{3}{*}{ MT10 } & B & 416 & 1.90 & 2.08 & 15 & 28.46 \\
\hline & $\mathrm{M}$ & 279 & 0.45 & 1.40 & 10 & 4.49 \\
\hline & $\mathrm{S}$ & 105 & 0.06 & 0.53 & 6 & 0.38 \\
\hline
\end{tabular}

With respect to captured biomass, the ANOVA results were $(F 9 ; 110=0.848 ; \mathrm{p}=0.573)$ with 
no significance for lath spacing (Figure 5).

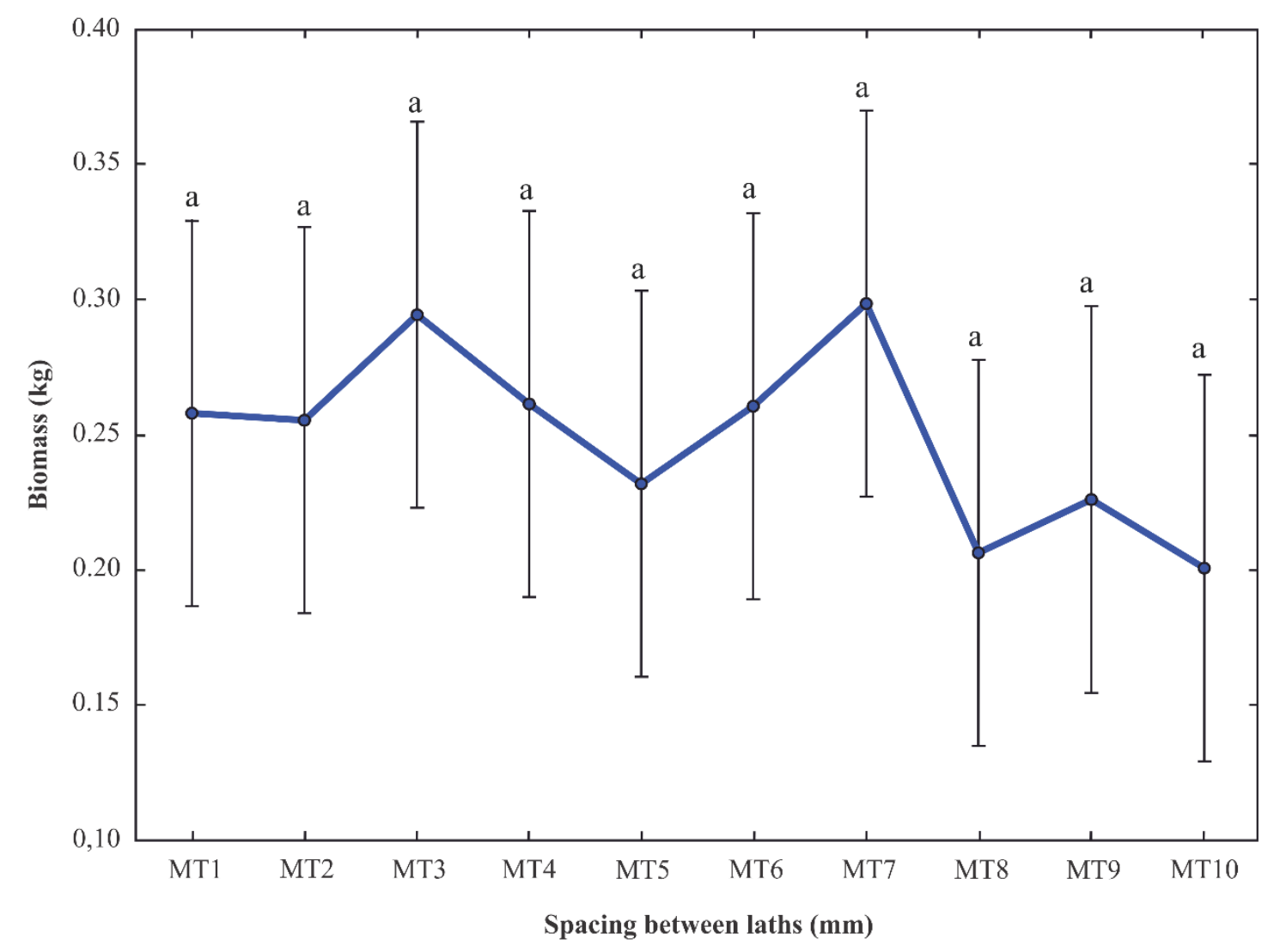

Figure 5. Biomass (kg) captured for different matapi (matapi + matapi cover) lath spacing size. The bars indicate the confidence interval. Data collected monthly between May 2018 and April 2019. Values with the same lowercase letters are not significant

Based on lengths and biomass of captured specimens it was observed that the spacing between laths of 8 to $10 \mathrm{~cm}$ capture larger shrimp and in greater abundance than the other spacings. According to Silva et al. (2016), the recruitment period of Amazonian shrimp has a peak in the month of July, and $70.7 \%$ of juvenile Amazonian shrimp make up the stock that comprises the range of $19.09 \mathrm{~mm}$ to $41.09 \mathrm{~mm}$ of standard length (corresponding to 0.6 to 1.6 of carapace length). Therefore, it could be deduced that the use of lath spacings below $7 \mathrm{~mm}$, common among fishing communities in the region (5 $\mathrm{mm}$ is generally the spacing used), could be negatively affecting renovation of the natural stock of shrimp in the region. Similarly, Silva et al. (2007) demonstrated that fishing pressure on the population of $M$. amazonicum at Combú island, state of Pará, is having a negative effect. For the region of Amapá, Lima (2014a, 2014b) suggested an adjustment of the laths of traditional traps to a minimum distance of $1.0 \mathrm{~cm}$, and the establishment of a minimum capture size of $7.0 \mathrm{~cm}$ of total length, which corresponds to $1.6 \mathrm{~cm}$ of carapace length.

The length of carapace of captured shrimp for different lath spacings was significant ( $F$ $(9: 13377)=271.18 ; \mathrm{p}=0.0000)$, with matapis using spacings of 7 to $10 \mathrm{~mm}$ individuals with greater average values (Figure 6). 


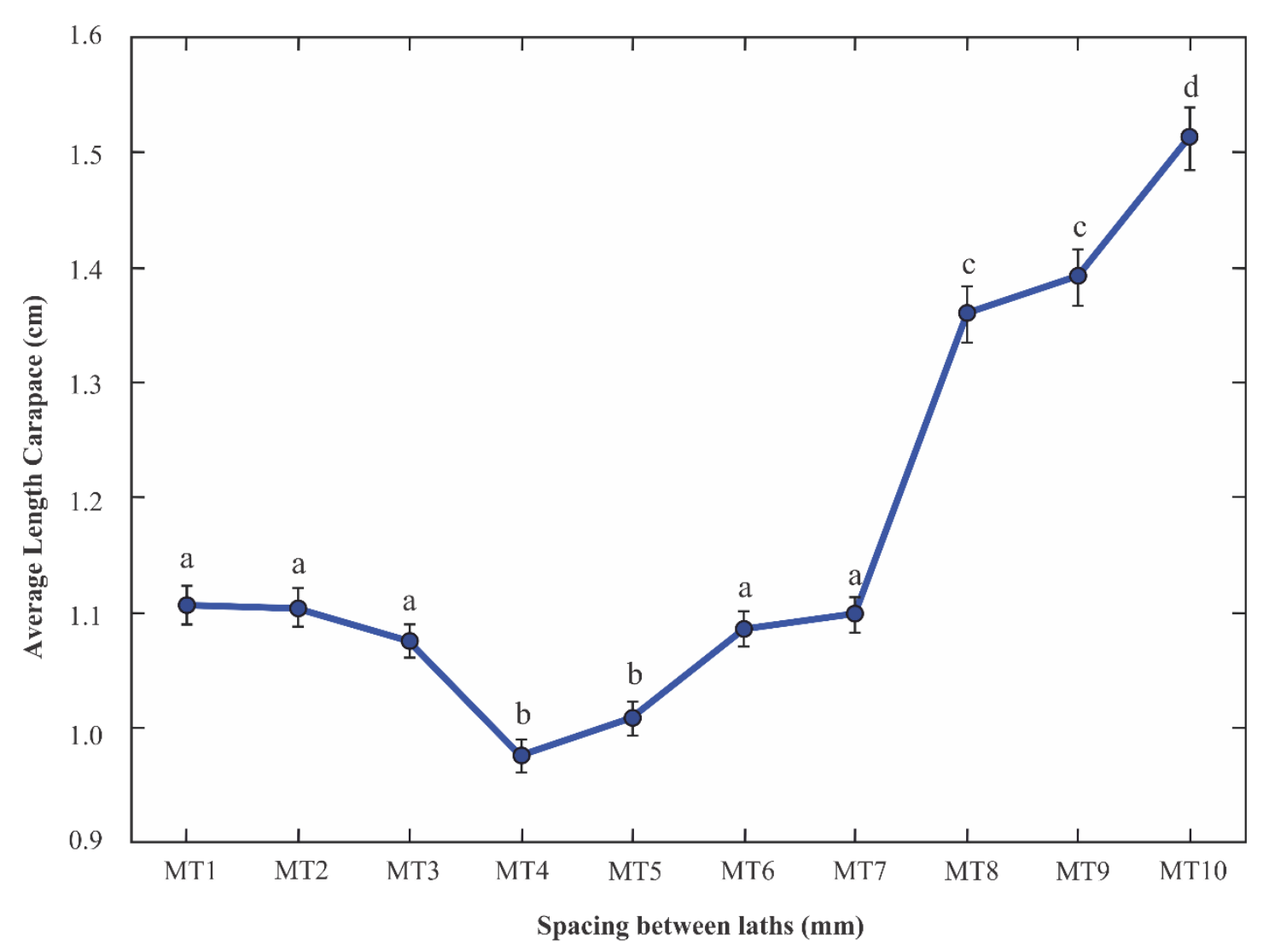

Figure 6. Average length of carapace for lath spacings of matapis. The bars indicate the confidence interval for the averages. Data collected monthly between May 2018 and April 2019. Values with the same lowercase letters are not significant 
Table 2. Frequency and composition of capture of the Amazonian shrimp (Macrobrachium amazonicum) for different spacings between laths, Santana island, city of Santana. Data collected monthly between May 2018 and April 2019

\begin{tabular}{ccccccc}
\hline Lath spacing $(\mathrm{mm})$ & Place of capture & $\mathrm{N}$ & $\%$ & Min & AVG \pm SD & Max \\
\hline 1 & Matapi & 1796 & 10.26 & 0.5 & $1.14 \pm 0.43$ & 3 \\
& Matapi cover & 252 & & 0.5 & $0.87 \pm 0.37$ & 2.7 \\
\hline 2 & Matapi & 1778 & 10.47 & 0.5 & $1.16 \pm 0.0 .4$ & 3 \\
& Matapi cover & 313 & & 0.4 & $0.76 \pm 0.16$ & 1.5 \\
\hline 3 & Matapi & 2407 & 13.78 & 0.2 & $1.12 \pm 0.36$ & 2.9 \\
& Matapi cover & 345 & & 0.2 & $0.75 \pm 0.13$ & 1.4 \\
\hline 4 & Matapi & 1832 & 15.28 & 0.1 & $1.11 \pm 0.34$ & 3 \\
& Matapi cover & 1219 & & 0.3 & $0.77 \pm 0.25$ & 2.2 \\
\hline 5 & Matapi & 1457 & 12.14 & 0.1 & $1.14 \pm 0.38$ & 2.7 \\
& Matapi cover & 966 & & 0.4 & $0.81 \pm 0.20$ & 1.9 \\
\hline 6 & Matapi & 1261 & 11.48 & 0.2 & $1.20 \pm 0.41$ & 3 \\
& Matapi cover & 1031 & & 0.4 & $0.94 \pm 0.21$ & 1.8 \\
\hline 7 & Matapi & 1262 & 12.86 & 0.5 & $1.33 \pm 0.40$ & 3 \\
& Matapi cover & 1305 & & 0.4 & $0.88 \pm 0.21$ & 2.1 \\
\hline \multirow{2}{*}{6} & Matapi & 614 & 4.67 & 0.6 & $1.60 \pm 0.47$ & 3.3 \\
& Matapi cover & 319 & & 0.5 & $0.89 \pm 0.20$ & 2.1 \\
\hline & Matapi & 625 & 5.05 & 0.5 & $1.60 \pm 0.46$ & 2.9 \\
& Matapi cover & 384 & & 0.5 & $1.06 \pm 0.34$ & 2.3 \\
\hline & Matapi & 354 & 4.01 & 0.6 & $1.79 \pm 0.38$ & 2.9 \\
& Matapi cover & 446 & & 0.6 & $1.29 \pm 0.32$ & 2.3 \\
\hline & & & & & &
\end{tabular}

$A V G \pm S D=$ Mean \pm Standard Deviation

The frequency and composition of capture for different spacings between laths is shown in Table 2, and the selectivity analysis is shown in Table 3 . The lengths for which $25 \%, 50 \%$ and $75 \%$ of the captured shrimp are grouped are shown in Table 3. 
Table 3. Selectivity curve (SL) equations and values for $\mathrm{L}_{25}$, L50 and $\mathrm{L}_{75}$ of the different matapi lath spacings (between 1 and $10 \mathrm{~mm}$ ) used in the capture of the Amazonian shrimp (Macrobrachium amazonicum) for different spacings between laths, Santana island, city of Santana. Data collected monthly between May 2018 and April 2019

\begin{tabular}{ccccc}
\hline Lath spacing $(\mathrm{mm})$ & $\mathrm{L}_{25}$ & $\mathrm{~L}_{50}$ & $\mathrm{~L}_{75}$ & Equations \\
\hline 1 & 0.001 & 0.34 & 0.69 & $\mathrm{~S} 1=1 /[1+\exp (1.103-3.197 * \mathrm{LC})]$ \\
2 & 0.41 & 0.6 & 0.79 & $\mathrm{~S} 2=1 /\left[1+\exp \left(2.529-5.868^{*} \mathrm{LC}\right)\right]$ \\
3 & 0.31 & 0.52 & 0.72 & $\mathrm{~S} 3=1 /\left[1+\exp \left(2.779-5.416^{*} \mathrm{LC}\right)\right]$ \\
4 & 0.35 & 0.72 & 1.09 & $\mathrm{~S} 4=1 /\left[1+\exp \left(2.099-2.910^{*} \mathrm{LC}\right)\right]$ \\
5 & 0.5 & 0.8 & 1.1 & $\mathrm{~S} 5=1 /[1+\exp (2.936-3.663 * \mathrm{LC})]$ \\
6 & 0.47 & 0.96 & 1.45 & $\mathrm{~S} 6=1 /\left[1+\exp \left(2.150-2.238^{*} \mathrm{LC}\right)\right]$ \\
7 & 0.78 & 1.02 & 1.26 & $\mathrm{~S} 7=1 /\left[1+\exp \left(4.756-4.658^{*} \mathrm{LC}\right)\right]$ \\
8 & 0.71 & 0.94 & 1.16 & $\mathrm{~S} 8=1 /[1+\exp (4.606-4.913 * \mathrm{LC})]$ \\
9 & 0.6 & 1.2 & 1.8 & $\mathrm{~S} 9=1 /\left[1+\exp \left(2.201-1.832^{*} \mathrm{LC}\right)\right]$ \\
10 & 1.32 & 1.85 & 2.37 & $\mathrm{~S} 10=1 /\left[1+\exp \left(3.907-2.113^{*} \mathrm{LC}\right)\right]$ \\
\hline
\end{tabular}

Recruitment data reported by Silva et al. (2016) reinforce the necessity of adoption of such recommendations for the Amazonian shrimp. The increase of space between laths for size 8 $\mathrm{mm}$ to $10 \mathrm{~mm}$ makes the trap more selective, drastically reducing the volume of juvenile individuals that are captured, and increases the capture of medium and large-sized shrimp (Lima, 2014a), a fact that is shown by the L50 of the selectivity curves.

The size at the initial maturation of $M$. amazonicum has been reported as being between 4.5 $\mathrm{cm}$ and $6.0 \mathrm{~cm}$ in total length (approximately $0.9 \mathrm{~cm}$ to $1.3 \mathrm{~cm}$ of carapace length) (Sampaio et al., 2007; Freire et al., 2012; Lima et al., 2014; Bentes et al., 2016), and this clearly shows that larger spacings capture much larger shrimp than those at the size at initial maturation, independent of sex and collection period. However, due to variations in population structure, size, fecundity and fertility among the continental and estuarine populations of $M$. amazonicum, there is a necessity to establish differentiated planning measures to organize the framework that regulates the fishing of these shrimp, including improvements of the fishing equipment and establishing the minimum size for capture of $M$. amazonicum in the Amazon, tailored to peculiarities of each region.

The selectivity curves demonstrate that, when considering that size at initial sexual maturation varies between $0.9 \mathrm{~cm}$ and $1.3 \mathrm{~cm}$ in carapace length, more than $50 \%$ of young shrimp would be protected by the use of traps with a spacing $\geq 7 \mathrm{~mm}$. Nevertheless, current regulations for the use of traps used to capture the Amazonian shrimp do not exist, and this severely limits the adequate management of this species. Some studies indicate that selective fishing based only on management models that establish a minimum capture size could compromise the shrimp population and the ecosystem, causing age suppression (Garcia et al., 2012), recruitment problems (Berkeley et al., 2004), early maturation of individuals 
(Jørgensen et al., 2007), thus favoring slower genotypes (Conover and Munch, 2002) and alteration of phenotypic variation (Zhou et al., 2010).

\section{Conclusion}

The matapis that have spacing between laths that is less than $7 \mathrm{~mm}$, currently used by riverine communities and artisanal fishermen (generally $5 \mathrm{~mm}$ ), can be considered predatory, since they permit the capture of small individuals, because in the current study more than $50 \%$ of shrimp were captured between spacings of 1 to $5 \mathrm{~mm}$. In spite of the fact that spacings of 8 to $10 \mathrm{~mm}$ between the laths captured a smaller quantity of shrimp, these spacings enable the capture of larger shrimp and a similar biomass yield, and for this reason these should be considered more viable in ecological and economic terms.

Therefore, in order to minimize the capture of young shrimp, without drastically affecting economic yield from this activity, it is suggested that the distance between the laths of the matapis be adjusted between 6 and $8 \mathrm{~mm}$. It is also recommended that this suggestion becomes incorporated into official laws that regulate the capture of the Amazonian shrimp at the mouth of the Amazon River.

\section{References}

Aya-Baquero, E., \& Velasco-Santamaria, Y. (2013). Fecundity and fertility of Macrobrachium amazonicum (Héller 1862) (Decápoda, Palaemonidae) of Colombian Piedemonte Llanero. Revista MVZ Córdoba, 18, 3773-3780.

Bentes, B., Martinelli, J. M., Lutz, I. A. F., Nascimento, M. S., \& Isaac, V. J. (2016). Population dynamics of Macrobrachium amazonicum (Heller, 1862) (Decapoda: Palaemonidae) in a Brazilian Amazon Estuary. Pan-American Journal of Aquatic Sciences, 11, 1-17. https://doi.org/10.1590/S1519-69842011000500013

Bentes, B., Martinelli, J. M., Lutz, I. A. F., Paes, E. T. Fernandes, S. C. P., Paula, J. D., \& Isaac, V. J. (2014). Experimental study on the efficiency of different types of traps and baits for harvesting Macrobrachium amazonicum (Heller, 1862). Acta Scientiarum Biological Sciences, Maringá, 36(4), 386-391. https://doi.org/10.4025/actascibiolsci.v36i4.22852

Berkeley, S. A., Hixon, M. A., Larson, R. J., \& Love, M. S. (2004). Fisheries sustainability via protection of age structure and spatial distribution of fish populations. Fisheries Management $\quad$ Feature, 29, 23-32. https://doi.org/10.1577/1548-8446(2004)29[23:FSVPOA]2.0.CO;2

Biello, D. (2006). Overfishing could take seafood off the menu by 2048. Available: https://www.scientificamerican.com/article/overfishing-could-take-se/. (November 2, 2006).

Conover, D. O., \& Munch, S. B. (2002). Sustaining fisheries yields over evolutionary time scales. Science, 297, 94-96. https://doi.org/10.1126/science.1074085

Costa, D. A. S., Martins, J. C., Silva, K. C. A., Klautau, A. G. C. M., \& Cintra, I. H. A. (2016). Seletividade do Matapi nas capturas de Macrobrachium amazonicum no baixo rio Tocantins, Amazônia, Brasil. Boletim do Instituto de Pesca, 42, 403-417. 
https://doi.org/10.20950/1678-2305.2016v42n2p403

Delgado, C. L., Nikolas, W., Mark, W., Rosegrant, S. M., \& Mahfuzuddin A. (2003). Fish to 2020, Suplly \& Demand in Changing Global Markets. WorldFish Conter Techincal Report, Wahington, D.C. \& Penang Malaysia. p 232. Available: https://www.fcrn.org.uk/sites/default/files/IFPRI_Fish_to_2020.pdf

FAO (2012). The State of World Fisheries and Aquaculture 2012. Fisheries and Aquaculture Department. Food and Agriculture Organization of the United Nations. Roma. p. 230. Available: http://www.fao.org/3/a-i2727e.pdf

Flexa, C. E., Silva, K. C. A., \& Cintra, I. H. A. (2005). Morfometria do camarão-canela, Macrobrachium amazonicum (Heller, 1862), no município de Cametá - Pará. Boletim Técnico-Científico do CEPNOR, 5, 41-54. https://doi.org/10.32519/tjfas.v5i1.1250

Freire, J. L., Bentes, B., Fontes, V. B., \& Silva, E. M. (2017). Morphometric discrimination among three stocks of Macrobrachium amazonicum in the brazilian Amazon. Limnologica, 64, 1-10. https://doi.org/10.1016/j.limno.2017.01.007.

Freire, J. L., Marques, C. B., \& Silva, B. B. (2012). Estrutura populacional e biologia reprodutiva do camarão-da-Amazônia Macrobrachium amazonicum (Heller, 1862) (Decapoda: Palaemonidae) em um estuário da região nordeste do Pará, Brasil. Brazilian Journal Aquatic Science and Technology, 6, 65-76. https://doi.org/10.14210/bjast.v16n2.p65-76.

Garcia, S. M., Kolding, J., Rice, J., Rochet, M. J., Zhou, S., Arimoto, T., ... Smith, A. D. M. (2012). Reconsidering the consequences of selective fisheries. Science, 335, 1045-1047. https://doi.org/10.1126/science.1214594.

Hammer, Ø., Harper, D. A. T., \& Ryan, P. D. (2001). PAST: Paleontological Statistics Software Package for Education and data analysis. Palentologia Electronica, 4(1) 9. Available: http://palaeo-electronica.org/2001_1/past/issue1_01.htm.

Jones, R. (1976). South China Sea fisheries development and coordinating programme. Mesh regulation in the demersal fisheries of the south China Sea area, Regional. 87p.

Jørgensen, C., Enberg, K., Dunlop, E. S., Arlinghaus, R., Boukal, D. S., Brander, K., ... Rijnsdorp, A. D. (2007). Ecology: Managing evolving fish stocks. Science, 318, 1247-1248. https://doi.org/10.1126/science.1148089

Lima J. F., Silva L. M. A., Silva T. C., Garcia J. S., Pereira I. S., \& Amaral K. D. S. (2014). Reproductive aspects of Macrobrachium amazonicum (Decapoda: Palaemonidae) in the state of Amapá, Amazon River mouth. Acta Amazônica, 44, 245-254. https://doi.org/10.1590/S0044-59672014000200010

Lima, J. D. F. (2014a). Viabilidade de matapis adaptados com diferentes espaçamentos entre talas sobre a captura do camarão da Amazônia (Macrobrachium Amazonicum Heller, 1862) no estuário do Rio Amazonas. Embrapa Amapá-Comunicado Técnico (INFOTECA-E). 


\section{MInstitute}

Journal of Agricultural Studies

ISSN 2166-0379

2020, Vol. 8, No. 3

Lima, J. D. F. (2014b). Indicadores e sugestões para o ordenamento da pesca artesanal do camarão-da-amazônia no Estuário amazônico.Embrapa Amapá-Comunicado Técnico (INFOTECA-E)

Lima, J. D. F., \& Montagner, D. (2014). Aspectos gerais da pesca e comercialização do camarão-da-amazônia no Amapá.Embrapa Amapá-Documentos (INFOTECA-E).

Melo, G. A. S. (2003). Família Palaemonidae, In: Melo, G.A.S. Manual deIdentificação dos Crustacea Decapoda de água doce do Brasil. Edições Loyola.

Moraes-Valenti, P., \& Valenti, W. C. (2010). Culture of the Amazon river prawn Macrobrachium amazonicum. In: M. B. New, W. C. Valenti, J. H., Tidwell, L. R. D’Abramo \& M. N. Kutty, (Eds). Freshwater prawns: biology and farming. (pp. 485-501). Oxford: Wiley-Blackwell.

Odinetz-Collart, O. (1987). La pêche crevettière de Macrobrachium amazonicum (PALAEMONIDAE) dans le Bas Tocantins, aprés la fermeture du barrage du Tucurui. Revue d'Hydrobiologie Tropicale, 20(2), 31-144. Available: http://horizon.documentation.ird.fr/exl-doc/pleins_textes/cahiers/hydrob-trop/25176.pdf

Pantaleão, J. A. F., Hirose, G. L., \& Costa, R. C. (2012). Relative growth, morphological maturity, and size of Macrobrachium amazonicum (Heler, 1862) (Crustacea, Decapoda, Palaemonidae) in a population with na entirely freshwater life cycle. Invertebrate Reproduction and Development, 180-190. https://doi.org/10.1080/07924259.2011.587276

Pope, J. A., Margetts, A. R., Hamley, J. M., \& Akiüz, E. F. (1983). Manual de métodos para la evaluación de las poblaciones de peces. Parte 3. Selectividad del arte de pesca (Vol. 41). Food \& Agriculture Org. Available.

Rocha, S. S., Silva, R. L. S., Santos, J. L., \& Oliveira, G. (2015). Length-weight relationship and condition factor of Macrobrachium amazonicum (Heller, 1862) (Decapoda, Palaemonidae) from a reservoir in Bahia, Brazil. Nauplius, 23(2), 149-161. https://doi.org/10.1590/S0104-64972015002308.

Sainsbury, J. C. (1986). Commercial Fishing Methods: An Introduction to Vessels and Gears. ( $3^{\mathrm{a}}$ ed.) Oxford: Cambridge. p. 359.

Sampaio, C. M. S., Silva, R. R., Santos, J. A., \& Sales, S. P. (2007). Reproductive cycle of Macrobrachium amazonicum females (Crustacea, Palaemonidae). Brazilian Journal of Biology, 67(3), 551-559. https://doi.org/10.1590/S1519-69842007000300022

Silva, K. C. A., Cintra, I. H. A., \& Muniz, A. P. M. (2005). Aspectos bioecológicos de Macrobrachium amazonicum (Heller,1862) a jusante do reservatório da hidroelétrica de Tucuruí - Pará. Boletim Técnico-Científico do CEPNOR, 5(1), 55-71. https://doi.org/10.32519/tjfas.v5i1.1251

Silva, K. C., Souza, R. A. L., \& Cintra, I. H. A. (2002). Camarão-cascudo Macrobrachium amazonicum (Heller, 1862) (Crustacea, Decapoda, Palaemonidae) no muncípio de 


\section{Macrothink}

Journal of Agricultural Studies

ISSN 2166-0379

2020, Vol. 8, No. 3

Vigia-Pará-Brasil. Boletim Técnico-Científico do CEPNOR, 2(1), 41-74. Available: https://www.icmbio.gov.br/cepnor/images/stories/publicacoes/btc/vol02/art02-v02.pdf

Silva, L. M. A., Lima, J. D. F., \& Takiyama, L. R. (2016). The recruitment pattern of Macrobrachium amazonicum (Crustacea, Decapoda, Palaemonidae) in two areas of the Amazon River mouth, Amapá State, Brazil. Biota Amazônia, 6(3), 97-101. https://doi.org/10.18561/2179-5746/biotamazonia.v6n3p96-101

Silva, M. C. N. (2006). Dinâmica Populacional do Camarão Cascudo, M. amazonicum (HELLER, 1962), da Ilha de Combu - Belém -PA. (Dissertação de mestrado) Universidade Federal Rural da Amazônia, Belém, Pará.

Silva, M. C. N., Fredou, F. L., \& Souto-Filho, J. (2007). Estudo do crescimento do camarão Macrobrachium amazonicum (Heller, 1862) da Ilha de Combu, Belém, Estado do Pará. Amazônia: Ciência e Desenvolvimento, 2(2), 85-104.

Swartz, W. U., Rashid, S., Reg, W., \& Pauly, D. (2010). Sourcing seafood for the three major markets: the EU, Japan \& the USA. Marine Policy, 4(6), 1366-1373. https://doi.org/10.1016/j.marpol.2010.06.011

Vieira, I. M., \& Araújo-Neto, M. D. (2006). Aspectos da socioeconomia dos pescadores de camarão da Ilha do Pará (Pa) e Arquipélago do Bailique (Ap). Boletim do Laboratório de Hidrobiologia, 19(1), 85-94. Available: http://www.periodicoseletronicos.ufma.br/index.php/blabohidro/article/view/2107

Worm, B., Hilborn, R., Baum, J. K., Branch, T. A., Collie, J. S., Costello, C., ... Zeller, D. (2009). Rebuilding Global Fisheries. Science, 325(5940), 578-585. https://doi.org/10.1126/science. 1173146

Zar, J. H. (1999). Biostatistical analysis. (3 ${ }^{\mathrm{a}}$ ed.). New Jersey: Prentice Hall. p. 662

Zhou, S., Smith, A. D. M., Punt, A.E., RIchardson, A. J., Gibbs, M., Fulton, E. A., ... Sainsbury, K. (2010). Ecosystem-based fisheries management requires a change to the selective fishing philosophy. Proceedings of the National Academy of Sciences of the USA, 10721(21), 9485-9489. https://doi.org/10.1073/pnas.0912771107

\section{Copyright Disclaimer}

Copyright for this article is retained by the author(s), with first publication rights granted to the journal.

This is an open-access article distributed under the terms and conditions of the Creative Commons Attribution license (http://creativecommons.org/licenses/by/4.0/). 